\title{
Pengaruh Asfiksia Neonatal Terhadap Gangguan Pendengaran
}

\author{
Gatot Irawan Sarosa, Alifiani Hikmah Putranti, Tri Kartika Setyarini \\ Bagian Ilmu Kesehatan Anak RSUP Dr Kariadi- Fakultas Kedokteran Universitas Diponegoro, Semarang
}

Latar belakang. Kejadian gangguan pendengaran di negara maju 1-3 dari 1000 kelahiran hidup, sedangkan prevalensi gangguan pendengaran di Indonesia $\pm 4,2 \%$, penyebabnya antara lain asfiksia. Identifikasi dini usia 3 bulan pertama kehidupan dan intervensi optimal 6 bulan pertama mencegah gangguan bicara, bahasa, kognitif, personal sosial, emosional, perilaku, akademik dan keterbatasan kesempatan kerja.

Tujuan. Membuktikan asfiksia sebagai faktor risiko gangguan pendengaran sensorineural dengan mempertimbangkan prematuritas, obat ototoksik, dan ventilator mekanik.

Metode. Penelitian observasional dengan rancangan kohort prospektif di RSUP Dr. Kariadi Semarang bulan Desember 2009 - November 2010. Subjek penelitian 68 neonatus terdiri dari 34 neonatus kelompok asfiksia dan 34 neonatus tanpa asfiksia Pemilihan subjek secara consecutive sampling, dicatat data klinis, laboratorium, dilakukan timpanometri, oto acustic emission (OAE) pertama usia < 1 bulan dan OAE kedua dan brainstem evoked response audiometry (BERA) usia 3 bulan. Analisis statistik dengan uji Chi-square, uji Mc Nemar dan uji t tidak berpasangan, regresi logistik.

Hasil. Kejadian gangguan pendengaran 35,3\% pada asfiksia berdasarkan OAE pertama ( $\mathrm{p}=0,003 ; \mathrm{RR}: 6,0$; 95\%CI:1,5-24,8), menjadi 20,6\% pada OAE kedua ( $\mathrm{p}=0,15)$. Gangguan pendengaran pada asfiksia berat $57,1 \%$ berdasarkan OAE pertama ( $\mathrm{p}=0,003)$, menjadi $28,6 \%$ pada OAE kedua $(\mathrm{p}=0,16)$. Gangguan pendengaran sedang pada asfiksia $11,8 \%$ berdasarkan BERA $(p=0,14)$. Faktor risiko prematuritas pada OAE pertama dan kedua $\mathrm{p}=1,00$. Obat ototoksik, ventilator mekanik dan gangguan pendengaran pada OAE pertama ( $\mathrm{p}=0,005$; RR:4,4; 95\%CI:1,3-14,3 dan $\mathrm{p}=0,03$; RR:3,5; 95\%CI:1,5-8,2). Analisis multi variat faktor risiko gangguan pendengaran untuk asfiksia (OR 1,3; 95\%CI 0,1 - 19,9; $\mathrm{p}=0,84$ ), obat ototoksik (OR 3,7; 95\%CI 0,3 - 55,0; p=0,34), ventilator mekanik (OR 1,5; 95\%CI 0,2-10,2;p=0,69)

Kesimpulan. Asfiksia merupakan faktor risiko gangguan pendengaran usia kurang dari satu bulan. Gangguan pendengaran terbanyak pada asfiksia berat. Obat ototoksik dan ventilator mekanik merupakan faktor risiko gangguan pendengaran usia kurang dari satu bulan. Prematuritas dan asfiksia, obat ototoksik, ventilator mekanik secara bersama-sama belum dapat disimpulkan sebagai faktor risiko gangguan pendengaran.

Sari Pediatri 2011;13(1):5-13.

Kata kunci: OAE, gangguan pendengaran, asfiksia neonatal.

\footnotetext{
Alamat korespondensi:

Dr. Gatot Irawan Sarosa, Sp.A. Bagian Ilmu Kesehatan Anak RSUP Dr Kariadi Semarang Jl Dr Sutomo 18 Semarang. E-mail: gt_irawan@ yahoo.com.
} 
$\mathrm{P}$ revalensi gangguan pendengaran bilateral kongenital sedang sampai sangat berat pada neonatus berkisar antara 1-3 dari 1000 kelahiran hidup. ${ }^{1}$ Survei Kesehatan Indera Pendengaran di tujuh propinsi tahun 1994-1996 menyebutkan prevalensi gangguan pendengaran dan ketulian di Indonesia $16,8 \%$ dan $0,4 \% .{ }^{2,3}$ Menurut data WHO tahun 2007, prevalensi gangguan pendengaran penduduk Indonesia diperkirakan 4,2\%.

Asfiksia adalah keadaan neonatus yang gagal bernapas secara spontan dan teratur saat lahir atau beberapa saat setelah lahir sehingga mengakibatkan kurangnya oksigenasi atau perfusi jaringan, ditandai dengan hipoksia, hiperkarbi, dan asidosis. ${ }^{5,6}$ Keadaan tersebut menyebabkan terjadi gangguan pendengaran. ${ }^{7}$

Deteksi dini gangguan pendengaran yang dapat digunakan pada bayi baru lahir adalah tes otoacoustic emissions (OAE), waktu pengerjaannya cepat, dan efektif mengukur aktifitas proses biomekanik koklea, terutama outer hair cell, yang merupakan organ yang pertama kali terkena akibat asfiksia. Sensitivitas OAE 98\%-100\%, spesifitas 94\%. ${ }^{8,9}$ Pemeriksaan brainstem evoked response audiometry (BERA) digunakan sebagai deteksi dini gangguan pendengaran karena dapat digunakan untuk segala usia, efektif mengukur abnormalitas telinga tengah dan dalam. Sensitivitas BERA $100 \%$, sedangkan spesifisitas $97-98 \% .^{3}$

\section{Metode}

Penelitian observasional telah dilakukan dengan rancangan kohort prospektif. Subyek penelitian adalah neonatus asfiksia dan neonatus tanpa asfiksia yang lahir dan dirawat di ruang bayi sehat, Perawatan Bayi Risiko Tinggi RSUP Dr. Kariadi Semarang, pada bulan Desember 2009 sampai November 2010

Kriteria inklusi adalah neonatus dengan asfiksia sedang (skor apgar $<7$ ) atau berat (skor apgar <4) dan neonatus tanpa asfiksia (skor apgar $\geq 7$ ) yang mendapatkan pengobatan sesuai protokol Subbagian Perinatologi, orang tua bersedia anak diikutsertakan dalam penelitian, dapat mengikuti penelitian sampai tiga bulan. Kriteria eksklusi adalah riwayat infeksi intrakranial, gejala klinis infeksi TORCH, kelainan kongenital, hiperbilirubinemia, dantuli konduktif. Subyek penelitian dipilih secara non-random sampling dengan metode consecutive sampling.
Subyek yang memenuhi kriteria inklusi dicatat data klinis selama perawatan, kemudian dilakukan pemeriksaan timpanometri dan OAE untuk menyingkirkan tuli konduktif serta gangguan pada koklea. Bulan ketiga dilakukan pemeriksaan timpanometri, OAE dan BERA. Pemeriksaan dilakukan ahli audiologi tanpa melihat status riwayat asfiksia pasien. Gangguan pendengaran ditentukan berdasarkan hasil pemeriksaan OAE atau BERA.

Uji hipotesis menggunakan uji $\chi^{2}$. Risiko gangguan pendengaran pada analisis bivariat dinyatakan sebagai risiko relatif (RR). Pengaruh variabel perancu yaitu prematuritas, obat ototoksik (gentamisin), dan ventilator mekanik terhadap hubungan antara asfiksia dengan kejadian gangguan pendengaran dilakukan uji regresi logistik dan dinyatakan sebagai adjusted odd ratio (OR). Batas kemaknaan bila $\mathrm{p}<0,05$.

Protokol penelitian telah mendapat persetujuan dari Komisi Etik Penelitian Kedokteran FK UNDIP/ RSDK No.108/EC/FK/RSDK/2009 dan Direktur SDM dan Pendidikan RSUP Dr. Kariadi Semarang No. DL.00.02.Diklit.2375. Persetujuan keluarga dalam bentuk informed consent tertulis. Penanganan pasien sesuai protokol di Subbagian Perinatologi, Identitas pasien dirahasiakan.

\section{Hasil}

Selama periode Desember 2009 sampai November 2010 didapat 68 neonatus yang memenuhi kriteria inklusi, terdiri 34 neonatus dengan skor Apgar $<7$ sebagai kelompok asfiksia dan 34 neonatus dengan skor Apgar $\geq 7$ sebagai kelompok tanpa asfiksia.

Karekteristik ke dua kelompok tidak berbeda kecuali usia subyek saat pemeriksaan pertama kelompok asfiksia lebih tua dibanding tanpa asfiksia.

Hasil pemeriksaan pendengaran berdasarkan pemeriksaan OAE pertama dan kedua tertera pada Tabel 2.

Kejadian gangguan pendengaran kelompok asfiksia 35,3\% sedangkan tanpa asfiksia 5,9\%. Asfiksia neonatal merupakan faktor risiko terjadinya gangguan pendengaran berdasarkan pemeriksaan OAE pertama, dengan risiko enam kali lebih besar terjadi gangguan pendengaran dibandingkan tanpa asfiksia. Kelompok asfiksia 20,6\% terdapat gangguan pendengaran sedangkan tanpa asfiksia 5,9\%. Asfiksia neonatal bukan faktor risiko gangguan pendengaran 
berdasarkan pemeriksaan OAE kedua. Kejadian gangguan pendengaran berdasarkan pemeriksaan $\mathrm{OAE}$ pertama dan kedua pada kelompok asfiksia dan tanpa asfiksia tertera pada Tabel 3.

Pada kelompok asfiksia, 12 subyek terdapat gangguan pendengaran pada pemeriksaan OAE pertama, $50 \%$ di antaranya masih terdapat gangguan pendengaran pada pemeriksaan OAE kedua. Hasil normal pemeriksaan OAE pertama 22 subyek, 4,5\% di antaranya terdapat gangguan pendengaran pada pemeriksaan OAE kedua.

Pada kelompok tanpa asfiksia, 2 subyek terdapat gangguan pendengaran pada pemeriksaan OAE pertama dan semuanya menjadi normal pada pe-

Tabel 1. Karakteristik subyek penelitian

\begin{tabular}{lcc}
\hline \multirow{2}{*}{ Karakteristik } & \multicolumn{2}{c}{ Kelompok } \\
\cline { 2 - 3 } & $\begin{array}{c}\text { Asfiksia } \\
\mathrm{n}=34\end{array}$ & $\begin{array}{c}\text { Tanpa asfiksia } \\
\mathrm{n}=34\end{array}$ \\
\hline Jenis kelamin bayi; $\mathrm{n}(\%)$ & $20(58,8)$ & $17(50)$ \\
$\quad$ - Laki-laki & $14(41,2)$ & $17(50)$ \\
$\quad$ Cerempuan & & \\
Cara lahir; $\mathrm{n}(\%)$ & $8(23,5)$ & $9(26,5)$ \\
$\quad$ - Spontan & $16(47,1)$ & $21(61,8)$ \\
- Sectio caesaria & $10(29,4)$ & $4(11,8)$ \\
- Ekstraksi vakum & $3082,4 \pm 397,94$ & $3105,9 \pm 508,98$ \\
Rerata berat lahir (gram) & $7,1 \pm 2,01$ & $7,1 \pm 2,83$ \\
Rerata kadar bilirubin indirek (mg/dL) & $7,5 \pm 1,99$ & $7,5 \pm 2,76$ \\
Rerata kadar bilirubin total (mg/dL) & $4,4 \pm 2,31$ & $3,7 \pm 2,67$ \\
Rerata usia saat pemeriksaan pertama (hari) & $97,4 \pm 14,39$ & $98,6 \pm 12,74$ \\
Rerata usia saat pemeriksaan kedua (hari) & &
\end{tabular}

Tabel 2. Hasil pemeriksaan OAE pertama dan kedua

\begin{tabular}{|c|c|c|c|c|}
\hline \multirow[b]{2}{*}{ Kelompok } & \multicolumn{2}{|c|}{ Hasil pemeriksaan OAE } & \multirow{2}{*}{$\begin{array}{c}\mathrm{RR} \\
(95 \% \mathrm{CI})\end{array}$} & \multirow[b]{2}{*}{$\mathrm{P}$} \\
\hline & $\begin{array}{c}\text { Gangguan } \\
\text { pendengaran }(+)\end{array}$ & $\begin{array}{c}\text { Gangguan } \\
\text { pendengaran (-) }\end{array}$ & & \\
\hline \multicolumn{5}{|l|}{ Pertama, n(\%) } \\
\hline Asfiksia & $12(35,3)$ & $22(64,7)$ & $6,0(1,5-24,8)$ & $0,003^{ \pm}$ \\
\hline Tanpa asfiksia & $2(5,9)$ & $32(94,1)$ & & \\
\hline \multicolumn{5}{|l|}{ Kedua, n(\%) } \\
\hline Asfiksia & $7(20,6)$ & $27(79,4)$ & $3,5(0,8-15,7)$ & $0,15^{¥}$ \\
\hline Tanpa asfiksia & $2(5,9)$ & $32(94,1)$ & & \\
\hline
\end{tabular}

${ }^{£}$ Uji Chi-Square, ${ }^{¥}$ Uji Fisher-Exact

Tabel 3. Kejadian gangguan pendengaran berdasarkan pemeriksaan OAE pertama dan kedua

\begin{tabular}{|c|c|c|c|}
\hline \multirow[b]{2}{*}{ Hasil pemeriksaan OAE pertama } & \multicolumn{2}{|c|}{ Hasil pemeriksaan OAE kedua } & \multirow[b]{2}{*}{$\mathrm{p}$} \\
\hline & $\begin{array}{c}\text { Gangguan } \\
\text { pendengaran }(+)\end{array}$ & $\begin{array}{c}\text { Gangguan } \\
\text { pendengaran (-) }\end{array}$ & \\
\hline \multicolumn{4}{|l|}{ Kelompok asfiksia, n(\%) } \\
\hline - Gangguan pendengaran (+) & $6(50)$ & $6(50)$ & 0,139 \\
\hline - Gangguan pendengaran (-) & $1(4,5)$ & $21(95,5)$ & \\
\hline \multicolumn{4}{|l|}{ Kelompok tanpa asfiksia, $\mathrm{n}(\%)$} \\
\hline - Gangguan pendengaran (+) & $0(0,0)$ & $2(100)$ & 1,009 \\
\hline - Gangguan pendengaran (-) & $2(6,3)$ & $30(93,7)$ & \\
\hline
\end{tabular}

' Uji Mc Nemar 
meriksaan OAE kedua. Hasil normal pemeriksaan OAE pertama 32 subyek, 6,3\% di antaranya terdapat gangguan pendengaran pada pemeriksaan OAE kedua. Uji statistik menunjukkan hasil pemeriksaan OAE pertama dan kedua pada kedua kelompok tidak berbeda bermakna.

Hubungan derajat asfiksia dengan kejadian gangguan pendengaran berdasarkan pemeriksaan $\mathrm{OAE}$ pertama dan kedua tertera pada Tabel 4 .

Berdasarkan pemeriksaan OAE pertama, asfiksia berat $57,1 \%$ terjadi gangguan pendengaran sedangkan asfiksia sedang 29,6\%, secara statistik menunjukkan perbedaan bermakna. Berdasarkan pemeriksaan
OAE kedua, asfiksia berat $28,6 \%$ terjadi gangguan pendengaran sedangkan asfiksia sedang $18,5 \%$, secara statistik tidak berbeda bermakna.

Hasil pemeriksaan pendengaran berdasarkan pemeriksaan BERA pada kedua kelompok penelitian tertera pada Tabel 5 .

Subyek yang mengalami gangguan pendengaran pada kelompok asfiksia terbanyak derajat sedang $(11,8 \%)$ sedangkan tanpa asfiksia seluruhnya derajat ringan. Hubungan faktor yang berpengaruh terhadap kejadian gangguan pendengaran berdasarkan pemeriksaan OAE pertama dan kedua tertera pada Tabel 6 dan 7.

Tabel 4. Derajat asfiksia berdasarkan hasil pemeriksaan OAE pertama dan kedua

\begin{tabular}{|c|c|c|c|c|c|c|}
\hline \multirow[b]{2}{*}{ Derajat asfiksia n(\%) } & \multicolumn{3}{|c|}{ Pemeriksaan OAE pertama } & \multicolumn{3}{|c|}{ Pemeriksaan OAE kedua } \\
\hline & $\begin{array}{c}\text { Gangguan } \\
\text { pendengaran } \\
(+)\end{array}$ & $\begin{array}{c}\text { Gangguan } \\
\text { pendengaran } \\
(-)\end{array}$ & $\mathrm{p}$ & $\begin{array}{c}\text { Gangguan } \\
\text { pendengaran } \\
(+)\end{array}$ & $\begin{array}{c}\text { Gangguan } \\
\text { pendengaran } \\
(-)\end{array}$ & $\mathrm{p}$ \\
\hline Asfiksia berat (Apgar <4) & $4(57,1)$ & $3(42,9)$ & $0,003 £$ & $2(28,6)$ & $5(71,4)$ & $0,16 £$ \\
\hline Asfiksia sedang (Apgar 4-6) & $8(29,6)$ & $19(70,4)$ & & $5(18,5)$ & $22(81,5)$ & \\
\hline Tidak asfiksia (Apgar $\geq 7$ ) & $2(5,9)$ & $32(94,1)$ & & $2(5,9)$ & $32(94,1)$ & \\
\hline
\end{tabular}

$£$ Uji Chi-Square

Tabel 5. Hasil pemeriksaan gangguan pendengaran berdasarkan pemeriksaan BERA

\begin{tabular}{lccccc}
\hline & \multicolumn{4}{c}{ Hasil pemeriksaan BERA } & \\
\cline { 2 - 5 } Kelompokn(\%) & $\begin{array}{c}\text { Gangguan } \\
\text { pendengaran } \\
\text { berat }\end{array}$ & $\begin{array}{c}\text { Gangguan } \\
\text { pendengaran } \\
\text { sedang }\end{array}$ & $\begin{array}{c}\text { Gangguan } \\
\text { pendengaran } \\
\text { ringan }\end{array}$ & $\begin{array}{c}\text { Tanpa } \\
\text { gangguan } \\
\text { pendengaran }\end{array}$ & $\mathrm{p}$ \\
\hline Asfiksia & $1(2,9)$ & $4(11,8)$ & $2(5,9)$ & $27(79,4)$ & $0,14 £$ \\
Tanpa asfiksia & $0(0,0)$ & $0(0,0)$ & $2(5,9)$ & $32(94,1)$ & \\
\hline
\end{tabular}

${ }^{£}$ Uji Chi-Square

Tabel 6. Faktor yang berpengaruh terhadap kejadian gangguan pendengaran berdasarkan hasil pemeriksaan OAE pertama

\begin{tabular}{|c|c|c|c|c|}
\hline \multirow[b]{2}{*}{ Variabel } & \multicolumn{2}{|c|}{ Hasil pemeriksaan OAE pertama } & \multirow{2}{*}{$\begin{array}{c}\mathrm{RR} \\
(95 \% \mathrm{CI})\end{array}$} & \multirow[b]{2}{*}{$\mathrm{p}$} \\
\hline & $\begin{array}{c}\text { Gangguan } \\
\text { pendengaran }(+)\end{array}$ & $\begin{array}{c}\text { Gangguan } \\
\text { pendengaran (-) }\end{array}$ & & \\
\hline \multicolumn{5}{|c|}{ Prematuritas, $\mathrm{n}(\%)$} \\
\hline Ya & $0(0,0)$ & $2(100)$ & - & $1,00^{¥}$ \\
\hline Tidak & $14(21,2)$ & $52(78,8)$ & & \\
\hline \multicolumn{5}{|c|}{ Obat ototoksik, $\mathrm{n}(\%)$} \\
\hline $\mathrm{Ya}$ & $11(35,5)$ & $20(64,5)$ & 4,4 & $0,005^{£}$ \\
\hline Tidak & $3(8,1)$ & $34(91,9)$ & $(1,3-14,3)$ & \\
\hline \multicolumn{5}{|c|}{ Ventilator mekanik, $\mathrm{n}(\%)$} \\
\hline $\mathrm{Ya}$ & $4(57,1)$ & $3(42,9)$ & 3,5 & $0,03^{¥}$ \\
\hline Tidak & $10(16,4)$ & $51(83,6)$ & $(1,5-8,2)$ & \\
\hline
\end{tabular}

¥ Uji Fisher-exact

${ }^{\star}$ Uji Chi-Square 
Gatot Irawan Sarosa dkk: Pengaruh asfiksia neonatal terhadap gangguan pendengaran

Tabel 7. Faktor yang berpengaruh terhadap kejadian gangguan pendengaran berdasarkan hasil pemeriksaan OAE kedua

\begin{tabular}{|c|c|c|c|c|}
\hline \multirow[b]{2}{*}{ Variabel } & \multicolumn{2}{|c|}{ Hasil pemeriksaan OAE kedua } & \multirow{2}{*}{$\begin{array}{c}\mathrm{RR} \\
(95 \% \mathrm{CI})\end{array}$} & \multirow[b]{2}{*}{$\mathrm{p}$} \\
\hline & $\begin{array}{c}\text { Gangguan } \\
\text { pendengaran }(+)\end{array}$ & $\begin{array}{c}\text { Gangguan } \\
\text { pendengaran (-) }\end{array}$ & & \\
\hline \multicolumn{5}{|c|}{ Prematuritas, $\mathrm{n}(\%)$} \\
\hline Ya & $0(0,0)$ & $2(100)$ & - & $1,00^{*}$ \\
\hline Tidak & $9(13,6)$ & $57(86,4)$ & & \\
\hline \multicolumn{5}{|c|}{ Obat ototoksik, n(\%) } \\
\hline Ya & $7(22,6)$ & $24(77,4)$ & 4,2 & $0,07^{*}$ \\
\hline Tidak & $2(5,4)$ & $35(94,6)$ & $(0,9-18,7)$ & \\
\hline \multicolumn{5}{|c|}{ Ventilator mekanik, n(\%) } \\
\hline Ya & $2(28,6)$ & $5(71,4)$ & 2,5 & $0,23^{*}$ \\
\hline Tidak & $7(11,5)$ & $54(86,8)$ & $(0,6-9,7)$ & \\
\hline
\end{tabular}

$¥$ Uji Fisher-exact

Tabel 8. Analisis regresi logistik pengaruh asfiksia neonatal, obat ototoksik dan ventilator mekanik terhadap kejadian gangguan pendengaran berdasarkan pemeriksaan OAE pertama dan kedua

\begin{tabular}{lcccccc}
\hline \multirow{2}{*}{ Faktor risiko } & \multicolumn{3}{c}{ Hasil pemeriksaan OAE pertama } & \multicolumn{3}{c}{ Hasil pemeriksaan OAE kedua } \\
\cline { 2 - 7 } & $\begin{array}{c}\text { Adjusted } \\
\text { OR }\end{array}$ & 95\% CI & $\mathrm{p}$ & $\begin{array}{c}\text { Adjusted } \\
\text { OR }\end{array}$ & $95 \% \mathrm{CI}$ & $\mathrm{p}$ \\
\hline Asfiksia neonatal & 5,0 & $0,5-49,1$ & 0,17 & 1,3 & $0,1-19,9$ & 0,84 \\
Obat ototoksik & 1,5 & $0,2-11,8$ & 0,71 & 3,7 & $0,3-55,0$ & 0,34 \\
Ventilator mekanik & 3,0 & $0,5-16,9$ & 0,22 & 1,5 & $0,2-10,2$ & 0,69 \\
\hline
\end{tabular}

Risiko relatif (RR) prematuritas terhadap terjadinya gangguan pendengaran berdasarkan pemeriksaan OAE pertama dan kedua tidak dapat dihitung. Berdasarkan pemeriksaan OAE pertama, obat ototoksik dan ventilator mekanik merupakan faktor risiko gangguan pendengaran. Neonatus yang mendapat obat ototoksik mempunyai risiko 4,4 kali lebih besar terjadi gangguan pendengaran dibanding yang tidak mendapat obat ototoksik. Neonatus yang menggunakan ventilator mekanik mempunyai risiko 3,5 kali lebih besar terjadi gangguan pendengaran dibanding tanpa ventilator mekanik. Berdasarkan pemeriksaan OAE kedua, obat ototoksik dan ventilator mekanik bukan faktor risiko gangguan pendengaran.

Analisis regresi logistik pengaruh asfiksia neonatal, obat ototoksik, dan ventilator mekanik terhadap kejadian gangguan pendengaran berdasarkan pemeriksaan OAE pertama dan kedua tertera pada Tabel 8.

Subyek dengan asfiksia neonatal, obat ototoksik, dan ventilator mekanik secara bersama-sama bukan faktor risiko terhadap gangguan pendengaran baik berdasarkan pemeriksaan OAE pertama maupun kedua.

\section{Pembahasan}

Menurut Lasky ${ }^{10}$ respon pertama terhadap suara dimulai sejak janin berusia 20-25 minggu dan maturasi system auditori terjadi pada masa gestasi 30 minggu. Kami mendapatkan, meskipun rerata usia pemeriksaan pertama berbeda bermakna namun usia neonatus termuda 35 minggu. Perbedaan tersebut tidak mempengaruhi hasil OAE karena secara anatomis dan fungsional koklea terbentuk sempurna saat kehamilan trimester kedua.

Asfiksia neonatal menyebabkan kerusakan koklea akibat kurangnya oksigenasi dan perfusi jaringan yang dapat berlanjut menjadi kematian sel melalui mekanisme selective neuronal necrosis dan apoptosis. ${ }^{7}$ Schmutzhard $\mathrm{dkk}^{11}$ menemukan caspase-3 yang merupakan marker apoptosis pada hair cell, sel ganglion spiral, dan sel marginalis dari stria vaskularis pada neonatus dengan asfiksia. Berdasarkan OAE pertama, dijumpai neonatus dengan asfiksia 35,3\% mengalami gangguan pendengaran sedangkan tanpa asfiksia hanya 5,9\%. Asfiksia neonatal merupakan faktor risiko terjadinya gangguan pendengaran berdasarkan pemeriksaan $\mathrm{OAE}$ 
pertama, dengan kemungkinan enam kali lebih besar terjadi gangguan pendengaran pada neonatus dengan asfiksia dibandingkan tanpa asfiksia. Hasil ini hampir sama dengan penelitian Flint ${ }^{12}$ yang melaporkan kejadian gangguan pendengaran pada anak dengan riwayat asfiksia neonatal adalah $36 \%(\mathrm{p}<0,05)$. Penelitian Jiang ${ }^{13}$ pada neonatus aterm dengan asfiksia melaporkan kejadian gangguan pendengaran yang lebih rendah, 9,5-22,2\% ( $<<0,05)$. Pemeriksaan pada penelitian Jiang ${ }^{13}$ dilakukan pada usia satu bulan, sedangkan pada penelitian kami dilakukan pada usia kurang dari 1 minggu. Perbedaan umur ini menyebabkan perubahan angka kejadian gangguan pendengaran karena sebagian besar kasus gangguan pendengaran pada asfiksia neonatal tidak permanen. Terdapat perbedaan bermakna kejadian gangguan pendengaran berdasarkan pemeriksaan OAE pertama dengan derajat asfiksia pada penelitian ini. Kejadian gangguan pendengaran terbanyak pada asfiksia berat sebesar 57,1\%. Hasil yang berbeda ditemukan Jiang $\mathrm{dkk}^{13}$ yaitu 18,5 $25,6 \%$ pada neonatus aterm $(\mathrm{p}<0,05)$ dan Kilic $\mathrm{dkk}^{14}$ $27,6 \%$ pada neonatus preterm $(\mathrm{p}<0,05)$ dengan asfiksia berat. Zang $\mathrm{dkk}^{15}$ mendapatkan neonatus aterm dengan asfiksia sedang dan berat $22,2 \%$ mengalami gangguan pendengaran berdasarkan OAE $(\mathrm{p}<0,01)$.

Kerusakan hair cell pada asfiksia sebagian bersifat reversibel, yang dapat terjadi karena perbaikan oksigenasi dan perfusi pada koklea hingga jaringan otak. ${ }^{16}$ Maturitas dan plastisitas jalur auditori mulai dari koklea berupa perubahan ukuran serta bentuk dari hair cell hingga maturitas fungsi sinap dan proses sentral auditori temporal otak yang ditunjukkan dengan perkembangan fungsi talamus-kortikal juga menyebabkan perbaikan hasil pemeriksaan. Plastisitas dipengaruhi pula oleh stimulasi kronik dan kompleks sehingga terjadi proses perbaikan sistem pendengaran. ${ }^{11,13}$ Pemeriksaan OAE kedua pada penelitian kami menunjukkan neonatus dengan riwayat asfiksia $20,6 \%$ mengalami gangguan pendengaran sedangkan neonatus tanpa riwayat asfiksia hanya 5,9\%, namun asfiksia neonatal belum dapat disimpulkan sebagai faktor risiko terjadinya gangguan pendengaran berdasarkan pemeriksaan OAE kedua. Penurunan kejadian gangguan pendengaran tersebut disebabkan terjadi perbaikan hasil pemeriksaan OAE pada delapan orang neonatus. Gangguan pendengaran pada asfiksia berat $28,6 \%$, sedangkan pada asfiksia sedang $18,5 \%$, namun secara statistik tidak berbeda bermakna. Hasil yang serupa pada penelitian Zang $\mathrm{dkk}^{15}$ dari 12 neonatus dengan asfiksia sedang dan berat yang mengalami gangguan pendengaran saat usia 1 bulan, 25\% menunjukkan hasil normal saat pemeriksaan OAE ulang usia 6 bulan, meskipun perbedaan tersebut tidak bermakna bila dibandingkan dengan hasil pemeriksaan OAE pertama. Orang tua pasien yang mengalami gangguan pendengaran pada pemeriksaan OAE pertama dilakukan edukasi dan pelatihan untuk memberikan stimulasi suara sesuai dengan Pedoman Pelaksanaan Stimulasi, Deteksi dan Intervensi Dini Tumbuh Kembang Anak. ${ }^{17}$

Patofisiologi delayed-onset gangguan pendengaran hingga saat ini masih belum jelas. ${ }^{18}$ Terdapat delapan neonatus yang mengalami perbaikan pada pemeriksaan OAE kedua, tiga neonatus yang mengalami delayedonset gangguan pendengaran, terdiri satu $(4,5 \%)$ neonatus dengan riwayat asfiksia dan dua (6,3\%) neonatus tanpa riwayat asfiksia, hasil pemeriksaan OAE pertama normal tetapi pemeriksaan OAE kedua terdapat gangguan pendengaran. Penelitian retrospektif oleh Weichbold dkk ${ }^{19}$ menemukan dari 105 neonatus dengan hasil normal pada pemeriksaan OAE saat usia kurang dari 7 hari, 23 (22\%) subyek mengalami delayed-onset gangguan pendengaran pada usia 1-63 bulan. Satu (4,3\%) subyek diantaranya dengan riwayat asfiksia berat mengalami gangguan pendengaran sedang pada usia 26 bulan. Terdapat $6(26 \%)$ subyek tanpa faktor risiko mengalami gangguan pendengaran sedang (3 subyek) dan berat (3 subyek) saat usia 8-58 bulan. Pemeriksaan OAE dan BERA ulang akan dilakukan pada usia 6 bulan.

Penyebab gangguan pendengaran pada asfiksia neonatal diduga karena adanya kerusakan sel otak akibat keadaan hipoksia dan iskemia sehingga distribusi oksigen ke berbagai jaringan menurun. Tahap awal terjadi mekanisme kompensasi berupa peningkatan aliran darah ke otak yang dipicu oleh penurunan resistensi serebrovaskular dan hipertensi sistemik. Pada asfiksia berat aliran darah ke otak justru menurun akibat peningkatan resistensi serebrovaskular. Fase lanjut terjadi kegagalan mekanisme homeostatis dimana curah jantung menurun dan terjadi hipotensi sistemik dengan akibat penurunan aliran darah ke otak. ${ }^{7}$ Proses tersebut terjadi pada sel otak dan batang otak dalam waktu 10 menit setelah terjadi hipoksia. Tingkat kerusakan sel sangat dipengaruhi lama dan derajat asfiksia. ${ }^{11}$ Derajat gangguan pendengaran berdasarkan pemeriksaan BERA pada usia tiga bulan tidak menunjukkan perbedaan antara neonatus dengan 
asfiksia dan tanpa asfiksia. Gangguan pendengaran pada neonatus dengan asfiksia terbanyak derajat sedang $(11,8 \%)$ sedangkan tanpa asfiksia seluruhnya derajat ringan. Weichbold $\mathrm{dkk}^{19}$ mendapatkan gangguan pendengaran sedang $6,7 \%$ terjadi pada anak dengan riwayat asfiksia berat. Jiang $\mathrm{dkk}^{20}$ melaporkan asfiksia neonatal mempengaruhi komponen perifer dan sentral pendengaran, karena neonatus dengan asfiksia dijumpai hasil refer pada pemeriksaan OAE dan peningkatan yang bermakna interval III-V dan I-III pada pemeriksaan BERA. Schmutzhard $\mathrm{dkk}^{11}$ melaporkan adanya apoptosis pada jaringan telingan dalam, namun tidak dijumpai apoptosis pada jaringan lobus temporalis pada neonatus asfiksia. Terbukti bahwa hipoksia menyebabkan kerusakan koklea terlebih dahulu dibanding kerusakan jaringan otak. ${ }^{11}$

Prematuritas merupakan salah satu faktor yang mempengaruhi terjadinya asfiksia. ${ }^{21}$ Faktor prematuritas tidak bermakna terhadap kejadian gangguan pendengaran pada pemeriksaan OAE pertama maupun kedua. Meyer $\mathrm{dkk}^{22}$ dan Ohl $\mathrm{dkk}^{23}$ juga mendapatkan bahwa faktor prematuritas tidak bermakna terhadap terjadinya gangguan pendengaran.

Ototoksisitas aminoglikosid berhubungan dengan lama terapi, konsentrasi dalam serum, kombinasi terapi dengan obat ototoksik lain, dan paparan langsung pada organ. ${ }^{24,25}$ Joint Committee on Infant Hearing menyatakan bahwa pemberian obat ototoksik $>5$ hari berisiko terjadi gangguan pendengaran. ${ }^{25}$ Konsentrasi puncak obat ototoksik dalam serum adalah 5-10 mg/L yang dicapai dengan dosis 4-5 mg/ $\mathrm{kg} /$ hari. Konsentrasi $>10 \mathrm{mg} / \mathrm{L}$ diduga berperan pada kerusakan vestibulokoklear sehingga pemantauan konsentrasi obat dalam serum sebaiknya dilakukan secara serial. ${ }^{27}$ Beberapa penelitian menunjukkan bahwa konsentrasi obat ototoksik dalam perilymph berhubungan dengan konsentrasi dalam serum. ${ }^{25}$ Obat ototoksik (gentamisin) merupakan faktor risiko gangguan pendengaran berdasarkan pemeriksaan OAE pertama, dengan kemungkinan 4,4 kali lebih besar dibandingkan yang tidak mendapat obat ototoksik. Zamani $\mathrm{dkk}^{24}$ juga mendapatkan obat ototoksik (gentamicin dan amikacin) berhubungan bermakna dengan gangguan pendengaran pada usia kurang dari tiga bulan. Kami memberikan gentamisin dengan dosis $5-7 \mathrm{mg} / \mathrm{kg} /$ hari dosis tunggal dan hanya lima pasien yang mendapatkan terapi lebih dari lima hari. Konsentrasi obat ototoksik dalam serum tidak dapat diperiksa karena tidak tersedia sarana. Tidak ada pasien yang mendapat terapi kombinasi dengan obat otoksik lain.

Penggunaan ventilator mekanik berpengaruh terhadap kejadian gangguan pendengaran akibat bising (noise) alat tersebut sehingga menyebabkan kerusakan telinga dalam. Jenis kerusakan tergantung intensitas, lama pajanan dan frekuensi bising. Bising intensitas sedang (50-85 dB) mengakibatkan perubahan ringan pada silia dan Hensen's body yang sebagian masih reversibel. ${ }^{28}$ Penelitian tentang tingkat bising di NICU oleh Berg $\mathrm{dkk}^{29}$ mendapatkan rerata intensitas bising di NICU adalah $(56,96 \pm 2,71) \mathrm{dB}$ dengan intensitas puncak (82-102,1) dB. Joint Committee on Infant Hearing menyatakan penggunaan ventilator mekanik lebih dari lima hari berisiko terjadi gangguan pendengaran. ${ }^{26}$ Penggunaan ventilator mekanik merupakan faktor risiko gangguan pendengaran berdasarkan pemeriksaan OAE pertama, dengan kemungkinan 3,5 kali lebih besar. Temuan ini sesuai dengan penelitian Zamani $\mathrm{dkk}^{24}$ dan Hille $\mathrm{dkk}^{30}$ yang mendapatkan bahwa penggunaan ventilator mekanik berhubungan bermakna dengan gangguan pendengaran pada bayi usia kurang dari tiga bulan. Neonatus yang menggunakan ventilator mekanik pada penelitian ini adalah neonatus dengan asfiksia berat (7 neonatus) dengan lama penggunaan 1-3 hari. Pasca perawatan, paparan terhadap bising berkurang atau tidak ada dan terjadi plastisitas dan maturitas koklea sehingga pemeriksaan OAE kedua tidak bermakna.

Analisis multivariat menunjukkan asfiksia neonatal, obat ototoksik dan ventilator mekanik belum dapat disimpulkan sebagai faktor risiko gangguan pendengaran. Temuan tersebut berbeda dengan penelitian Hille $\mathrm{dkk}^{30}$ yang menemukan pada analisis multivariat asfiksia neonatal (OR 1,7; 95\%CI 1,0-2,7) dan ventilator mekanik lebih dari lima hari (OR 3,6; 95\%CI 2,1-6,0) merupakan faktor risiko gangguan pendengaran. Perbedaan tersebut kemungkinan karena jumlah subyek penelitian ini hanya 68 neonatus sedangkan penelitian Hille dkk ${ }^{30}$ lebih banyak yaitu 2186 neonatus sehingga dapat mempengaruhi hasil analisis.

Keterbatasan penelitian adalah tidak dapat melakukan pemeriksaan segera setelah lahir karena baru dapat dilakukan setelah pasien tidak memerlukan oksigenasi, tidak memeriksa konsentrasi obat ototoksik dalam serum karena tidak tersedia sarana, dan tidak memeriksa TORCH. 
Gatot Irawan Sarosa dkk: Pengaruh asfiksia neonatal terhadap gangguan pendengaran

\section{Kesimpulan}

Asfiksia merupakan faktor risiko gangguan pendengaran usia kurang dari satu bulan, gangguan pendengaran terbanyak pada asfiksia berat. Obat ototoksik dan ventilator mekanik merupakan faktor risiko gangguan pendengaran usia kurang dari satu bulan. Prematuritas dan asfiksia, obat ototoksik, ventilator mekanik secara bersama-sama belum dapat disimpulkan sebagai faktor risiko gangguan pendengaran.

Diperlukan penelitian lanjutan dengan jumlah sampel lebih besar dengan memperhatikan angka kejadian faktor risiko gangguan pendengaran selain asfiksia neonatal, dan perlu dilakukan pemeriksaan TORCH. Neonatus asfiksia, mendapat obat ototoksik gentamicin serta ventilator mekanik perlu skrining gangguan pendengaran untuk identifikasi, dan intervesi dini pada usia tiga bulan pertama khususnya bulan pertama kehidupan agar tumbuh kembang dapat optimal.

\section{Daftar pustaka}

1. Thompson DC, McPhilips H, Davis RL, Lieu TL, Homer CJ, Helfand M. Universal Newborn Hearing Screening. JAMA 2001; 286:2000-10.

2. Runjan L, Amir I, Suwento R. Skrining gangguan pendengaran pada neonatus risiko tinggi. Sari Pediatri 2005; 6:149-54.

3. Suwento R. Gangguan pendengaran pada bayi dan anak. Dalam: Abstrak seminar sehari penatalaksanaan gangguan pendengaran dan ketulian; Semarang; 2007 .h.1-12.

4. World Health Organization, situation review and update on deafness, hearing loss and intervention programmes: proposed plans of action for prevention and alleviation of hearing impairment in countries of the South-East Asia Region, 2007.

5. Dharmasetiawani N. Asfiksia dan resusitasi bayi baru lahir. Dalam: Kosim MS, Yunanto A, Dewi R, Sarosa GI, Usman A, penyunting. Buku Ajar Neonatologi. Edisi ke-1. Jakarta: IDAI, 2008. h.103-25.

6. Khreisat WH, Habahbeh Z. Risk factors of birth asphyxia: A study at Prince Ali Ben Al-Hussein Hospital. Pakistan J Med Science 2005; 21:30-2.

7. Menkes JH, Sarnat HB. Perinatal asphyxia and trauma. Edisi ke-6. Philadelphia: Lippincott Williams \& Wilkins, 2000.h.401-66
8. Cunningham M, Cox EO. Hearing assessment in infants and children : Recommendations beyond neonatal screening. Pediatrics 2003;111:436-40.

9. Stearn N, Swanepoel DW. Identifying hearing loss by means of iridology. African J Traditional, Compli and Altern Med 2007;4:205-14.

10. Lasky RE, Williams AL. The development of the auditory system from conception to term. NeoReviews 2005;6: 141-52.

11. Schmutzhard J, Glueckert R, Sergi C, Schwentner I, Abraham I, Schrott-Fischer A. Does perinatal asphyxia induce apoptosis in the inner ear?. Hear Res 2009;250:1-9

12. Flint EF. Severe childhood deafness in Glasgow, 1965 1979. J Laryngol Otol. 1983;97:421-5.

13. Jiang ZD. Maturation of peripheral and brainstem auditory function in the first year following perinatal asphyxia: a longitudinal study. J Speech Lang Hear Res 1998;41:83-93.

14. Kilic I, Karahan H, Kurt T, Ergin H, Sahiner T. Brainstem evoked response audiometry and risk factors in premature infants. Marmara Medical J 2007;20:21-8.

15. Zang Z, Wilkinson AR, Jiang ZD. Distortion product otoacoustic emissions at 6 months in term infants after perinatal hypoxia-ischaemia or with a low apgar score. Eur J Pediatr 2008; 167:575-8.

16. Jiang ZD, Yin R, Shao XM, Wilkinson AR. Brain-stem auditory impairment during the neonatal period in term infants after asphyxia: dynamic changes in brain-stem auditory evoked response to clicks of different rates. Clin Neurophysiol 2004;115:1605-15.

17. Departemen Kesehatan Republik Indonesia. Pedoman pelaksanaan stimulasi, deteksi dan intervensi dini tumbuh kembang anak. 2006.h.15-39.

18. Holster IR, Hoeve LJ, Wieringa MH, Willis-Lorrier RMS, Gier HHW. Evaluation of hearing loss after failed neonatal hearing screening. J Pediatr 2009;155:646-50.

19. Weichbold V, Nekahm-Heis D, Welzl-Mueller K. Universal newborn hearing screening and postnatal hearing loss. Pediatrics 2006;117:631-36.

20. Jiang ZD, Brosi DM, Wilkinson AR. Differences in impaired brainstem conduction between neonatal chronic lung disease and perinatal asphyxia. Clin Neurophysiol 2009;121:725-33.

21. Sills JH. Perinatal asphyxia. Dalam: Gomella TL, Cunningham MD, Eyal FG, Zenk KE, penyunting. Neonatology; Management, Procedures. On-Call Problems, Disease and Drug. Edisi ke-5. New York: McGraw-Hill, 2006.h.1-14. 
22. Meyer C, Witte J, Hildmann A, Hennecke KH, Schunck KU, Maul K dkk. Neonatal screening for hearing disorders in infants at risk: incidence, risk factors, and follow up. Pediatrics 1999;104:900-4.

23. Ohl C, Dornier L, Czajka C, Chobaut JC, Tavernier L. Newborn hearing screening on infants at risk. Int J Pediatr Otorhinolaryngol 2009;73:1691-5.

24. Zamani A, Daneshjou K, Ameni A, Takand J. Estimating the incidence of neonatal hearing loss in high risk neonates. Acta Medica Iranica 2004;42:176-80.

25. Hain TC. Ototoxic medications. Diunduh dari URL: http://www.tchain.com/otoneurology/disorders/bilat/ototoxins. html Diakses pada tanggal 10 Agustus 2009.

26. Joint Committee on Infant Hearing. Year 2007 position statement: principles and guidelines for early hearing detection and intervention programs. Pediatrics 2007; 120:898-921.

27. de Hoog M, van den Anker JN. Therapeutic drug monitoring of aminoglycoside in neonates. Clin Pharmacokinet 2009;48:343-5.

28. Bashirudin J, Soetirto I. Gangguan pendengaran akibat bising. Dalam : Buku Ajar Ilmu Kesehatan Telinga Hidung Tenggorok Kepala Leher. Edisi ke-6. Jakarta: Balai Penerbit FK UI; 2007. h.49-52.

29. Berg AL, Chavez CT, Serpanos YC. Monitoring noise levels in a tertiary neonatal intensive care unit. CICSD 2010; 37:69-72.

30. Hille ETM, van Straaten HLM, Verkerk PH. Prevalence and independent risk factors for hearing loss in NICU infants. Acta Pædiatrica 2007; 96:1155-8. 